\title{
State Fiscal Policies and Transitory Income Fluctuations
}

\begin{abstract}
State and local expenditure and tax revenue respond less to the business cycle than do federal spending and revenue, thereby reducing the countercyclicality of total government expenditure and revenue. This paper considers forces responsible for the cyclical pattern of state expenditure and revenue. Annual fluctuations in state personal income are associated with small changes in state spending and significant changes in tax receipts; receipt of federal grants is associated with greater state spending. Tax collections, and to a lesser degree expenditure, of larger states are more closely associated with annual income fluctuations than are the tax collections and expenditure of smaller states. These state size differences may proxy for other state characteristics, such as the extent to which a state faces interstate competition for mobile businesses and individuals, and the quality of state government. The spending and tax revenue of states with less mobile populations closely track income fluctuations, as does spending in states where convictions of public officials for federal corruption crimes are more common. In small states, and in states with more mobile populations and better corruption records, government expenditure and revenue appear to rise and fall less with income, and in that respect more closely resemble the federal government.
\end{abstract}

$\mathrm{n}$ the United States, fiscal policy is the province not only of the federal government but also of 50 state governments and their local governments. Collectively, these nonfederal governments accounted for roughly 40 percent of total government expenditure in 2007, and an even larger fraction of total government revenue. Since states and municipalities operate independently of the federal government and of each other, it follows that a significant portion of U.S. fiscal policy is uncoordinated. As a result, any deliberate countercyclical fiscal policy conducted by the federal government has the potential to be affected, possibly even undermined, by the actions of state and local governments. 
The federalist structure of U.S. fiscal policy would be of little macroeconomic consequence if states and localities behaved just like smaller versions of the federal government, but there is little reason to expect them to, and considerable evidence that they do not. States and localities differ from the federal government and from each other in the economic functions they serve, their average level and composition of expenditure, the extent to which they are subject to national economic shocks, and their beliefs about the role of government in managing the economy. Perhaps most important, state and local decisionmaking is driven by interests and constraints that differ from those of the federal government: states have incentives to pursue policies that benefit their own stakeholders, and they are subject to competition from other states.

The aggregate evidence for the postwar period suggests that during economic downturns, state and local tax collections decline less than do federal tax collections, and state government spending expands less than does federal spending. This general pattern has been mirrored in the recent U.S. experience. For example, in 2007 the federal government collected \$1.638 trillion in taxes other than social insurance contributions, a figure that declined substantially in the recent recession, to \$1.142 trillion in 2009 . State and local tax collections also declined, but much more gradually: from \$1.314 trillion in 2007 to $\$ 1.267$ trillion in 2009. Federal government spending of $\$ 3.458$ trillion in 2009 was $\$ 558$ billion greater than in 2007, whereas state and local spending of \$2.026 trillion in 2009 exceeded 2007 spending by just $\$ 115$ billion. ${ }^{1}$ Changes in federal expenditure and in state and local expenditure reflect policy changes as well as the changing incomes of the population. In addition, federal grants-in-aid to state and local governments rose by $\$ 104$ billion between 2007 and 2009; removing this component leaves self-financed aggregate state expenditure only $\$ 11$ billion larger in nominal terms, and smaller in real terms, during 2009 than in 2007. It is clear that state and local governments reacted to the recession that began at the end of 2007 very differently than did the federal government.

There are reasons to expect states not to expand their spending during recessions. Almost all state governments have annual balanced budget requirements, with only limited exceptions for bad economic times, so the declining tax revenue that characterizes most economic downturns is

1. The state and local totals are the sum of state, county, city, and other local taxes and spending. Federal and aggregate state and local government tax and expenditure data, both at annual and quarterly frequencies, are drawn from the U.S. national income and product accounts. 
likely to be accompanied by reduced spending. These balanced budget requirements certainly do not prevent states from financing additional spending with greater borrowing, as evidenced by the fact that many states do borrow, but the requirements raise the political and administrative costs of running deficits, since they commonly require that state legislatures enact extraordinary measures to undertake the necessary borrowing. States with balanced budget requirements can maintain or expand spending across the cycle by running budget surpluses during good economic times, which can then be drawn down during bad economic times, but in practice it has proved difficult for many states to conduct their fiscal affairs that way. Finally, the adoption of balanced budget requirements reflects a shared expectation among states that they will not make extensive use of debt finance to combat adverse economic developments.

A second reason why state governments might fail to increase expenditure during economic downturns is that the tax revenue reductions that accompany economic contractions generally discourage spending even in the absence of a requirement that budgets be balanced. It has been widely documented that the expenditure of subnational governments is significantly affected by cash windfalls, whether positive or negative; this is known as the "flypaper effect": money tends to stick where it hits. The flypaper effect was first observed in the context of intergovernmental grants, typically those from the federal government to state governments, which appeared to have a much greater impact on state spending than can be easily reconciled with the actual income and substitution effects of the grants.

There is considerable controversy over the origins of the flypaper effect, its magnitude, and whether it reflects political dynamics or more fundamental aspects of the way that individuals make decisions. ${ }^{2}$ But whatever its sources, the flypaper effect describes an empirical regularity: money in hand and available is more likely to be spent than is money that is not quite as readily available, even though it is fully obtainable. Although the flypaper effect is often interpreted narrowly to apply to specific categories of revenue and expenditure, a more general view (see, for example, Hines and Thaler 1995) is that it reflects a feature of human nature that applies broadly to many revenue sources and expenditure categories, and results from the difficulty that people have in not spending resources that are

2. See, for example, Hines and Thaler (1995), Strumpf (1998), and Baicker (2005). Knight (2002), Gordon (2004), and Lutz (2010) offer evidence and interpretations that the magnitude of the flypaper effect may be overstated by earlier studies that fail to control properly for the endogeneity of grant receipts to spending levels, although even the data presented by Lutz (2010) appear to be consistent with significant flypaper effects. 
available to them. Thus, for example, Olivier Blanchard, Florencio Lopezde-Silanes, and Andrei Shleifer (1994) report that firms obtaining cash windfalls from victorious lawsuits significantly increased their expenditure on acquisitions of other firms; and in the context of state reactions to economic fluctuations, Douglas Holtz-Eakin, Whitney Newey, and Harvey Rosen (1989) find that local revenue shocks are associated with subsequent spending increases by municipal governments. Any natural tendency of state governments to spend money that they have on hand reduces the likelihood that states will pursue countercyclical fiscal policies. ${ }^{3}$

Against these considerations, however, must be set the potential benefits of greater spending, including the avoidance of draconian budget cuts, during economic downturns. To the extent that tax cuts and greater government spending during recessions facilitate the employment of underutilized resources within a state, they have the potential to promote the welfare of state residents. ${ }^{4}$ Apart from any desire to put underutilized resources to work, states that can avoid damaging, cash flow-driven budget cuts during bad economic times have the potential to improve their own business conditions and property values. This may matter more for smaller (that is, less populous) states than for larger states: since they tend to face the most elastic populations of businesses and individuals, they may have the strongest incentives to avoid boom-and-bust fiscal cycles that, to the extent that they are inefficient or reduce welfare, could result in declining populations, incomes, and property values.

3. An additional reason why states might reduce expenditure during recessions is that state spending becomes more expensive, on an after-federal-tax basis, to the degree that fewer taxpayers itemize deductions or that those who do itemize face lower marginal tax rates. The ability of taxpayers who itemize on their federal income tax returns to take deductions for state and local income and property tax payments generally reduces the after-tax cost of state spending, and thereby encourages state governments to spend more than they would were state taxes nondeductible (Feldstein and Metcalf 1987). Given that only roughly one-third of American taxpayers itemize their deductions, however, and that the fraction itemizing does not appear to fall systematically during recessions (the numbers of taxpayers itemizing deductions rose during the 1980, 1991-92, and 2001 recessions, according to IRS data: "SOI Bulletin Historical Table 7," www.irs.gov/taxstats/article/0,,id=175812,00.html), the effect of tax deductibility on state expenditure is unlikely to account for significant expenditure reactions to economic downturns.

4. There is enormous controversy over the extent to which countercyclical fiscal policy influences the employment of resources during economic downturns. See, for example, Auerbach, Gale, and Harris (2010), Auerbach and Gorodnichenko (2010), Barro and Redlick (2009), Blanchard and Perotti (2002), Cogan and others (2010), Hall (2009), Romer and Romer (2010), and Woodford (2010). Gramlich (1997) identifies circumstances in which state governments might benefit from expanding the employment of underutilized resources through expansionary fiscal policies, and Bahl (1984) reviews older evidence of the association of state tax and spending policies and business cycle fluctuations. 
States differ in the extent to which their levels of expenditure and taxation vary over the business cycle. Changes in the expenditure and tax revenue of larger states are more positively correlated with state income fluctuations than are those of smaller states. This fiscal pattern of large versus small states may reflect the pressures that all governments face to spend money during the good times when it is available, and reduce expenditure at other times; the somewhat greater immobility of population and business activity in large states arguably makes it more feasible for their governments to follow such spending patterns than it is for smaller jurisdictions. Expenditure and tax revenue in states with less mobile populations (where mobility is measured by the fraction of adults born in a state who subsequently reside there), and in states whose public officials are frequently convicted of federal corruption crimes, exhibit correlations with income fluctuations similar to those of large states. This suggests that state size might proxy in these regressions for other attributes of larger states, such as relatively more captive populations of individuals and businesses, and perhaps lower quality of government.

Section I of this paper uses quarterly national income accounts data (available for states only as an aggregate) from 1947 to 2010 to identify the extent to which state and local tax revenue and spending change during national income fluctuations. This evidence suggests that the 2007-09 experience is unusual only in its magnitude: real federal tax collections per capita tend to decline in years in which the economy performs poorly, whereas state and local tax collections are much more stable; furthermore, federal government spending tends to rise more rapidly during bad economic times than it does during good times, a pattern that is much less evident among state and local governments.

Section II of the paper uses Census of Governments data to identify the determinants of state tax and spending patterns, distinguishing between large and small states. States exhibit marked propensities to spend out of federal grant dollars, and larger states display tax revenue and expenditure patterns that are more closely associated with income fluctuations than are those of smaller states. Section III concludes.

\section{Aggregate Patterns of Federal and State Taxes and Spending}

Expenditure by the federal government accounts for about 20 percent of aggregate national expenditure in virtually every year since World War II. Figure 1 depicts ratios of real federal spending and of real state and local 
Figure 1. Federal Spending and State and Local Spending, 1947Q1-2010Q1 ${ }^{\mathrm{a}}$

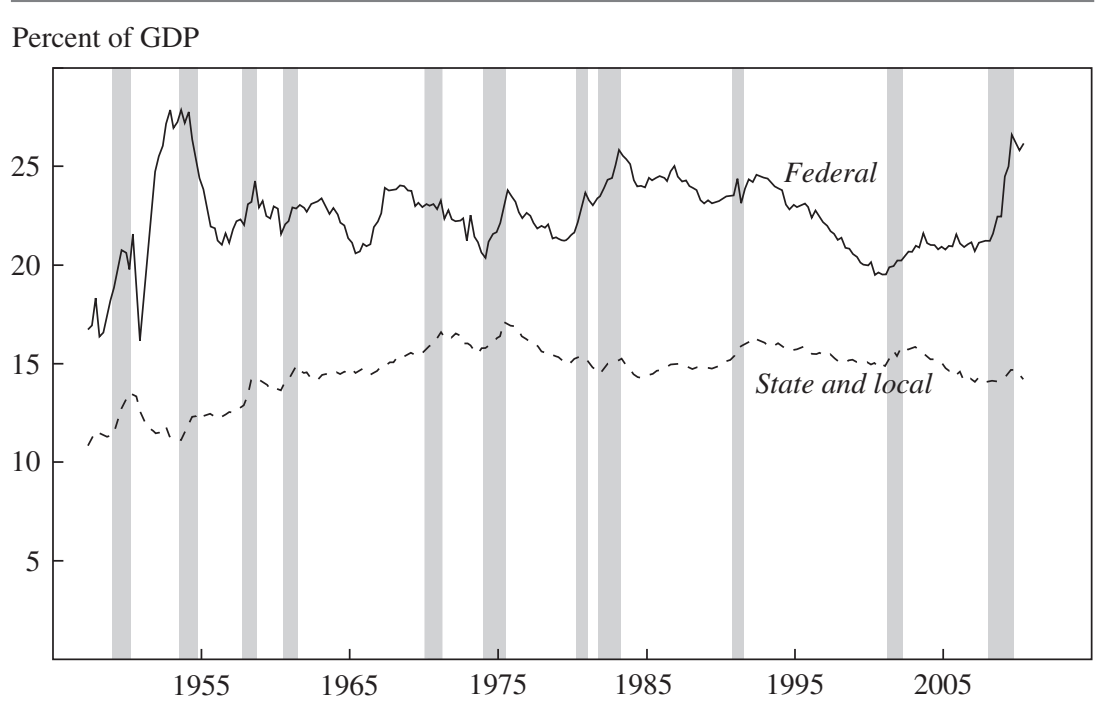

Source: National income and product accounts.

a. Shading indicates recessions as identified by the Business Cycle Dating Committee of the National Bureau of Economic Research.

spending to real U.S. GDP, as reported in quarterly national income account data from 1947Q1 to 2010Q1. ${ }^{5}$ It is noteworthy that federal spending as a fraction of GDP appears to rise with the onset of recessions, particularly since the 1960s. Doubtless recessions have this effect for multiple reasons, including not only that the federal government pursues a deliberately countercyclical fiscal policy, but also that a sluggish responsiveness of federal expenditure to changes in income means that the ratio rises when GDP fails to grow as rapidly as anticipated. Ratios of state and local expenditure to GDP appear to exhibit a similar pattern of rising in recessions, although from visual inspection it is not clear whether they do so to the same degree as federal expenditure. Certainly state and local spending

5. GDP, federal taxes, and state and local taxes are deflated using the GDP deflator. Government consumption and investment expenditures are separately deflated using the corresponding deflators, and all other categories of government expenditure (transfer payments, interest payments, and others) are deflated using the GDP deflator. 
during the 2007-09 recession did not rise as sharply as federal spending. ${ }^{6}$ But since the latest recession is just one of several postwar recessions, it is useful to consider how state and local spending and federal spending have responded in others.

Table 1 presents averages of quarterly growth rates of real federal government and aggregate state and local government tax revenue and spending per capita. ${ }^{7}$ These growth rates are calculated as first differences of the logarithms of seasonally adjusted quarterly values. Table entries are cell means; thus, for example, the first column indicates that, in quarters in which the output gap declined, the log of real federal income tax collections per capita rose by an average of 0.0177 . Strictly speaking, this corresponds to a growth rate of 1.79 percent, but as a convenient approximation, these log differences are commonly interpreted as percentage growth rates. The output gap is the difference between the economy's potential GDP and actual GDP, divided by potential GDP, as reported by the Congressional Budget Office.

The evidence in table 1 suggests that the cyclical patterns of U.S. federal tax and spending policies differ from those of state and local governments. In quarters during which the economy is expanding and the output gap is narrowing, the mean growth rate of real federal tax revenue per capita is 1.77 percent, whereas in quarters during which the output gap is widening, the mean growth rate of this revenue measure is -1.16 percent. State and local tax collections, by contrast, show a more muted difference, growing at a quarterly average rate of 1.13 percent when the output gap narrows and 0.27 percent when it widens. The last three columns of table 1 show that during recession quarters (as identified by the Business Cycle Dating Committee of the National Bureau of Economic Research), the mean growth rate of real federal tax revenue per capita is -2.91 percent, whereas at other times the mean growth rate is 1.08 percent; state and local tax revenue grew by an average of -0.02 percent during recession

6. Aizenman and Pasricha (2010) compare recent levels of certain (nontransfer) state and federal spending categories with levels predicted from a simple time-series model and argue that discretionary state fiscal policy is by this measure so contractionary that it roughly offsets the recent federal expansion. This conclusion appears to depend critically on the model used to predict discretionary spending; but almost any measure shows that state spending failed to expand during the 2007-09 recession, which suggests that states did not pursue active countercyclical policies.

7. Variables are converted to per capita terms using quarterly interpolations of annual population data from the U.S. Census. 


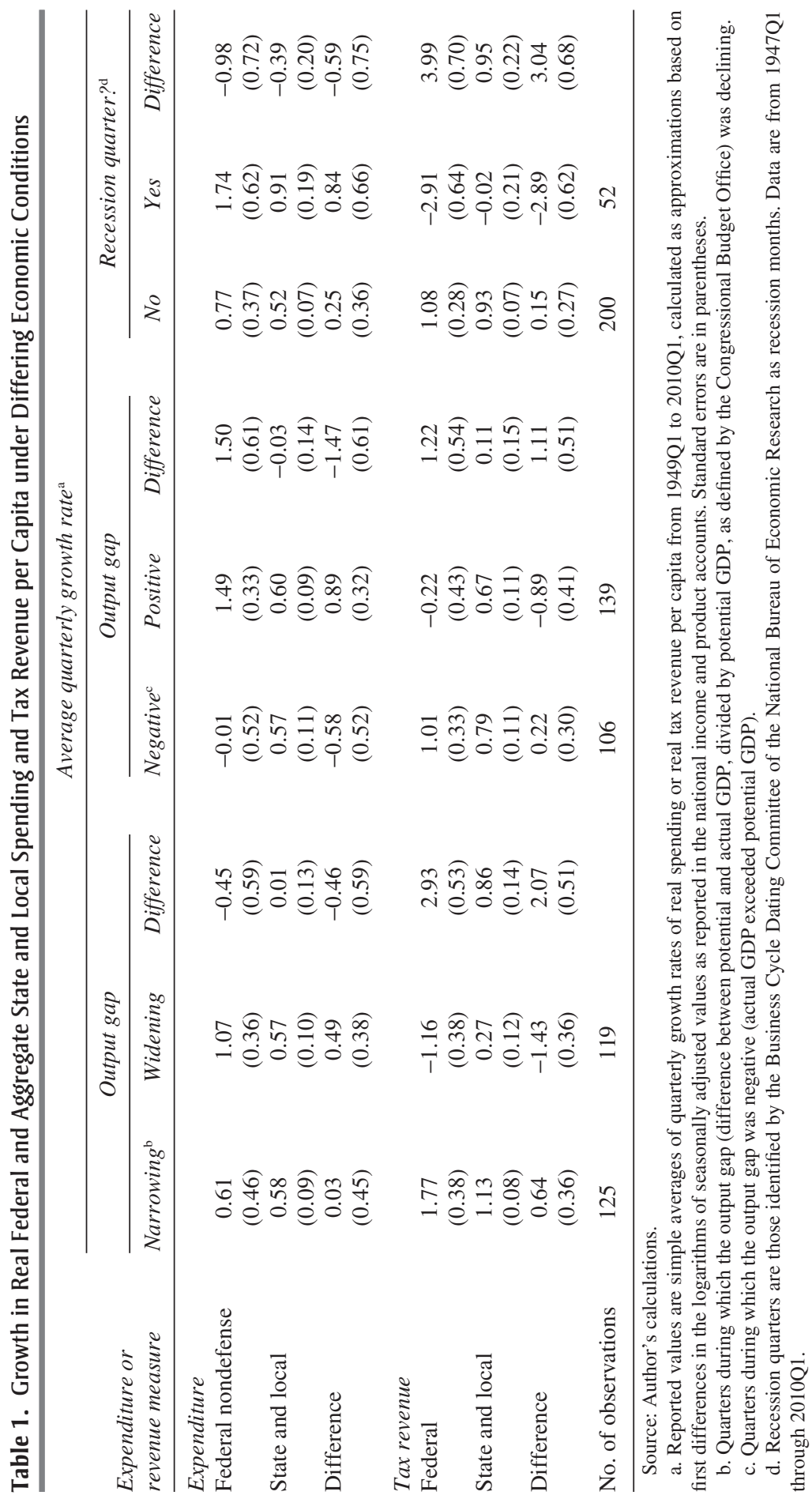


quarters, and 0.93 percent at other times. As the table indicates, these differences between federal and state and local tax revenue growth are statistically as well as quantitatively significant.

Federal spending tends to rise more rapidly when the economy is performing poorly than when it is performing well; state and local spending exhibits a similar pattern, but to a much smaller degree. Table 1 presents figures for federal nondefense expenditure, a portion of the federal budget that is less subject than total expenditure to exogenous shocks and more amenable to deliberate adjustment in response to changing macroeconomic conditions. Real federal nondefense spending per capita rose by a mean of 1.49 percent during quarters in which potential GDP exceeded actual, and at other times fell by an average of 0.01 percent. State and local government real expenditure per capita rose by an average of 0.60 percent during quarters in which potential GDP exceeded the actual; it also rose, by an average of 0.57 percent, at other times. As indicated in table 1, the relationship between federal expenditure growth and the output gap differs statistically from that between the growth of state and local spending and the output gap. The differences between federal and state and local spending growth during rising and falling output gaps, and during NBERdefined recessions, are not significant but point in the same direction: federal spending generally expands more than does state and local spending during difficult economic times.

In interpreting the evidence in table 1, it is important to bear in mind that these patterns reflect not only the degree to which the state of the economy may influence government tax and expenditure choices, but also the impact of taxes and government expenditure on economic performance. The federal government is larger, in terms of both revenue and spending, than the 50 state governments combined, and it is more likely to coordinate fiscal and monetary policy; as a result, federal actions have greater potential to influence the course of the economy. A simple interpretation of the means in table 1 might take the output gap and the cyclical status of the economy to be unaffected by government tax and spending changes, which is inaccurate if federal economic management is effective, and particularly if taxes and spending are coordinated with other government policies. To the extent that federal tax reductions and spending increases reduce the severity of economic downturns, simple interpretations of the statistics in table 1 understate the extent to which the federal government actively manages taxation and spending in response to underlying economic conditions. The same argument applies to state and local governments, although their smaller aggregate size gives it somewhat less significance. Further- 
more, one way in which the federal government actively manages aggregate demand during downturns is by using federal grant dollars and other inducements to encourage states to spend money; thus, some federal spending is effectively channeled through the states and appears as state expenditure even though it is largely federally determined.

Differences between federal fiscal policy and the fiscal policies of state and local governments reflect many considerations, including the federal government's explicit mandate to manage the economy over the business cycle, and the ability and desire of state governments to react to changing economic circumstances. Since states are heterogeneous, it is potentially instructive to compare the fiscal policies of states with differing characteristics, in order to identify factors that may contribute to the determination of overall state policies.

\section{Understanding State Fiscal Policy}

In the absence of countervailing policy action, tax revenue generally increases as incomes rise, creating opportunities for states to fund greater expenditure. A close connection between income changes and expenditure changes could, of course, constitute efficient state fiscal policy, although it also is characteristic of the flypaper effect as applied to state finances. To the extent that the flypaper effect is behavioral, fiscal policies driven by flypaper considerations are potentially costly from an efficiency standpoint. Small jurisdictions generally have the most elastic tax bases (Bucovetsky 1991, Kanbur and Keen 1993, Wilson and Wildasin 2004) and therefore face significant costs of adopting suboptimal policies that may chase away their business and individual populations. The very fact that adopting inefficient policies is so expensive has the potential to discipline politics in these smaller states to avoid some of the behavioral inefficiencies that could persist among their larger neighbors whose tax bases are more secure.

In evaluating state fiscal policy, then, it is instructive to distinguish between smaller and larger states in analyzing the impact of income fluctuations on taxes and expenditure. For that purpose it is necessary to use data from the Census of Governments. These data are available from 1951 to 2007 for the lower 48 states and the District of Columbia; coverage of Alaska and Hawaii is more limited, both in years and in data items, and so these states are omitted from the analysis. The data include information on state government expenditure, state personal incomes, populations, receipts of grants from the federal government, and collections of major 
sources of revenue. ${ }^{8}$ It is worth emphasizing that the present analysis does not use data on city, county, or other local taxes and spending, since the purpose is to analyze the determinants of taxes and spending at the state level. Personal income and state tax collections are converted to real 2005 dollars using the GDP deflator, and state government expenditure is converted to real 2005 dollars using the Bureau of Economic Analysis price index for state and local government consumption expenditure and gross investment; all variables are measured in per capita terms.

The state regressions include interactions between balanced budget requirements and changes in state incomes. Every state except Vermont has a formal requirement that its budget be balanced on an annual basis. However, these requirements vary considerably in their ability to constrain state legislatures, a fact that has permitted analysts to evaluate their impact by comparing the experiences of states with strict balanced budget laws with those that have more leeway to run deficits. Earlier research (for example, Poterba 1994, Alt and Lowry 1994) finds that states with more binding balanced budget requirements react to fiscal crises (variously defined) differently than do states with less binding requirements, although the reactions appear to be idiosyncratic in that they are influenced by local politics.

Poterba (1994, 1997), Von Hagen (1991), and numerous other studies use the characterization of state budget stringency from the now-defunct Advisory Commission on Intergovernmental Relations as their source of variation in state budget rules. In the simplest of these classifications, roughly half of the states are classified as having "strict" rules, with requirements that entail, if necessary, mid-year budget adjustments and actions by state executive agencies that make it politically costly (although by no means impossible) to run deficits. The regressions reported in tables 2,3 , and 4 include this variable interacted with changes in real state income per capita.

Columns 2-1 and 2-2 of table 2 report regressions in which the dependent variable is the first difference of the log of real state expenditure. The regressions include a complete set of year and state dummy variables. State population is entered as the difference between a state's share of the U.S. population and the sample mean of 0.0204; all other independent variables are entered as first differences in time. The estimated

8. Data on detailed categories of state government expenditure are not available for 2007. Annual state populations are available from the Census. 
Table 2. Regressions Explaining Annual Changes in State Spending and Tax Revenue

\begin{tabular}{|c|c|c|c|c|}
\hline \multirow[b]{3}{*}{ Independent variable ${ }^{\mathrm{b}}$} & \multicolumn{4}{|c|}{ Dependent variable ${ }^{\mathrm{a}}$} \\
\hline & \multicolumn{2}{|c|}{$\Delta$ log spending } & \multicolumn{2}{|c|}{$\Delta \log$ tax revenue } \\
\hline & $2-1$ & $2-2$ & $2-3$ & $2-4$ \\
\hline$\Delta$ income $^{\mathrm{c}}$ & $\begin{array}{c}-0.0159 \\
(0.0695)\end{array}$ & $\begin{array}{c}0.119 * * \\
(0.0588)\end{array}$ & $\begin{array}{l}0.368 * * * \\
(0.0836)\end{array}$ & $\begin{array}{l}0.367 * * * \\
(0.0836)\end{array}$ \\
\hline$\Delta$ income $_{-1}$ & $\begin{array}{c}0.0691 \\
(0.0598)\end{array}$ & $\begin{array}{c}0.101 * \\
(0.0593)\end{array}$ & $\begin{array}{l}0.299 * * * \\
(0.0551)\end{array}$ & $\begin{array}{l}0.304 * * * \\
(0.0591)\end{array}$ \\
\hline Balanced budget req. ${ }^{\mathrm{d}} \times \Delta$ income & $\begin{array}{c}0.00715 \\
(0.0798)\end{array}$ & $\begin{array}{l}-0.0160 \\
(0.0709)\end{array}$ & $\begin{array}{c}-0.0644 \\
(0.107)\end{array}$ & $\begin{array}{c}-0.0618 \\
(0.107)\end{array}$ \\
\hline Balanced budget req. $\times \Delta$ income $_{-1}$ & $\begin{array}{c}0.0186 \\
(0.0988)\end{array}$ & $\begin{array}{l}0.00722 \\
(0.0935)\end{array}$ & $\begin{array}{c}0.0796 \\
(0.0723)\end{array}$ & $\begin{array}{c}0.0769 \\
(0.0726)\end{array}$ \\
\hline Population $^{\mathrm{e}} \times \Delta$ income & $\begin{array}{l}-2.261 \\
(1.953)\end{array}$ & $\begin{array}{l}-0.740 \\
(1.751)\end{array}$ & $\begin{array}{l}9.975 * * * \\
(2.636)\end{array}$ & $\begin{array}{l}10.30 * * * \\
(2.757)\end{array}$ \\
\hline Population $\times \Delta$ income $_{-1}$ & $\begin{array}{l}4.714 * * \\
(2.066)\end{array}$ & $\begin{array}{l}4.778 * * \\
(2.237)\end{array}$ & $\begin{array}{l}4.881 * * * \\
(1.795)\end{array}$ & $\begin{array}{l}4.847 * * \\
(1.888)\end{array}$ \\
\hline Population & $\begin{array}{c}-1.374 \\
(3.788)\end{array}$ & $\begin{array}{c}1.170 \\
(3.194)\end{array}$ & $\begin{array}{l}-8.162 * * \\
(3.998)\end{array}$ & $\begin{array}{l}-8.534 * * \\
(4.140)\end{array}$ \\
\hline Population $_{-1}$ & $\begin{array}{c}1.675 \\
(3.768)\end{array}$ & $\begin{array}{c}-0.941 \\
(3.133)\end{array}$ & $\begin{array}{l}8.235^{* *} \\
(3.965)\end{array}$ & $\begin{array}{l}8.600 * * \\
(4.114)\end{array}$ \\
\hline$\Delta$ grants-income ratio $^{\mathrm{f}}$ & & $\begin{array}{l}4.862 * * * \\
(0.809)\end{array}$ & & $\begin{array}{c}0.100 \\
(0.447)\end{array}$ \\
\hline$\Delta$ grants-income ratio $_{-1}$ & & $\begin{array}{l}0.606^{*} \\
(0.311)\end{array}$ & & $\begin{array}{l}0.00611 \\
(0.361)\end{array}$ \\
\hline Population $\times \Delta$ grants-income ratio & & $\begin{array}{l}98.88 * * \\
(39.82)\end{array}$ & & $\begin{array}{l}17.53 \\
(20.58)\end{array}$ \\
\hline Population $\times \Delta$ grants-income ratio ${ }_{-1}$ & & $\begin{array}{c}-2.500 \\
(9.095)\end{array}$ & & $\begin{array}{c}-14.55 \\
(12.44)\end{array}$ \\
\hline$R^{2}$ & 0.279 & 0.348 & 0.270 & 0.270 \\
\hline
\end{tabular}

Source: Author's regressions.

a. Dependent variables are annual log changes in real state government spending or tax revenue per capita. All regressions include state and year fixed effects. Sample size is 2,695 in all regressions. Standard errors clustered at the state level are in parentheses.

b. Variables subscripted "-1" are one-year lags.

c. Annual change in the log of real state personal income per capita.

d. Dummy variable equal to 1 for states with a strict annual balanced budget requirement, and zero otherwise.

e. Difference between the state's population as a fraction of total U.S. population and the sample mean of 0.0204 .

f. Annual change in the ratio of federal grants to state personal income.

coefficients on the differences in log real income per capita (-0.0159), and its one-year lag (0.0691), in the regression in column 2-1, together imply that a 1 percent increase in income (measured as a deviation from the national average) in a state with population equal to the sample mean and no strict balanced budget requirement is accompanied by a 0.0532 percent rise in state spending. This is a very small effect, 
and statistically indistinguishable from zero, suggesting that short-term income changes have little average effect on state spending. The small size of the association may reflect a combination of deliberate countercyclical policy and sluggishness in adjusting spending to genuine income changes, together with any measurement error in state personal income. The positive coefficients on the interactions of the balanced budget requirement with the change in income in column 2-1 are consistent with expenditure by states with strict budgetary rules tracking state income changes more closely than does expenditure by other states. However, the small magnitudes and statistical insignificance of the coefficients suggest that balanced budget rules do not have powerful average effects over the sample period.

The coefficient on the interaction between (de-meaned) state population and the one-year-lagged change in income in column 2-1 (4.714) indicates that government spending by larger states is more positively associated with once-lagged income fluctuations than is government spending by smaller states. The negative coefficient on contemporaneous income changes in the same column $(-2.261)$ implies, however, that this association is mitigated by effects in the first year; the sum of these coefficients is 2.453 , with a standard error of 2.689. The regression reported in column 2-2 adds as explanatory variables the first difference of the ratio of grants received from the federal government to state personal income, the interaction of this variable with de-meaned state population, and lags of these two variables. The effect on spending of population interacted with lagged income changes continues to be positive, although the sum of this coefficient and the unlagged corresponding term is 4.038 , with a standard error of 2.938 that makes it insignificant.

Intergovernmental grants have the expected positive effect in the regression reported in column 2-2, the coefficients together implying that a state with mean population increases its expenditure by 5.468 percent as grants increase by 1 percent of state income. One way to interpret the impact of intergovernmental grants is to specify the change in state spending as a function of the change in state personal income and grant receipts:

$$
\Delta \ln S_{t}=\beta \Delta \ln \left(y_{t}+\gamma g_{t}\right),
$$

in which $S_{t}$ is state expenditure in year $t, y_{t}$ is state personal income in year $t, g_{t}$ is government grant receipts in year $t$, and $\Delta$ is the first difference operator. The parameter $\gamma$ reflects the fact that government grants may not affect spending to the same extent that personal income does; values of 
$\gamma>1$ correspond to larger effects of government grants. Equation 1 can be rewritten as

$$
\Delta \ln S_{t}=\beta \Delta \ln y_{t}+\beta \Delta \ln \left(1+\gamma \frac{g_{t}}{y_{t}}\right) .
$$

Using a first-order Taylor approximation to the second term on the right side of equation 2 , evaluated at the mean value of $\frac{g_{t}}{y_{t}}$, denoted $\left(\frac{g}{y}\right)$, produces

$$
\Delta \ln S_{t}=\beta \Delta \ln y_{t}+\beta \frac{\gamma}{\left[1+\gamma\left(\frac{g}{y}\right)\right]} \Delta \frac{g_{t}}{y_{t}}
$$

Column 2-2 presents estimated coefficients from a state spending regression that includes $\Delta \frac{g_{t}}{y_{t}}$ as an explanatory variable. Equation 3 implies that the ratio of the sum of grant effects (5.468) for a state with mean population to the sum of income effects for a state without a strict balanced budget requirement (0.22), which is 24.9, should equal $\frac{\gamma}{\left[1+\gamma\left(\frac{g}{y}\right)\right]}$, or (given the very small size of government grants relative to income) approximately $\gamma$. The estimates therefore imply that a dollar of grant receipt has about the same impact on state government spending as \$25 in additional state personal income per capita, which, if taken literally, implies that the marginal propensity to spend out of grant income is in the neighborhood of 80 percent. ${ }^{9}$ This clearly reflects not only the significant effects that grants have on spending levels, but also that grant receipts are influenced by state spending levels, sometimes on a one-for-one basis. It is noteworthy, however, that the 98.88 coefficient on the interaction of state population and federal grants suggests that whatever the process is that determines the association of state spending and federal grants, this process appears to operate more strongly for large states than for small states. This is consistent with a greater willingness of large states to spend out of transitory income, although it may also reflect aspects of the grant allocation process

9. The 0.220 estimated income elasticity in column 2-2, together with the 0.1475 mean ratio of state spending to state personal income, implies that, evaluated at the mean, the marginal propensity to spend by state government out of a dollar of personal income is $(0.22)(0.15)=0.033$. Then $(25)(0.033)=0.825$. 
that somehow reward expenditure by large states more than expenditure by small states.

Columns 2-3 and 2-4 of table 2 present estimated coefficients from regressions in which the dependent variable is the first difference of the log of state tax revenue, and the independent variables are the same as those used in the regressions reported in columns 2-1 and 2-2. State tax revenue rises with income: the sum of the first two coefficients in column 2-3 indicates that for a state with mean population and no strict balanced budget requirement, income growth by 1 percent is associated with 0.667 percent tax revenue growth. The significant positive coefficients on the interactions of population and the change in state personal income (current and lagged) imply that rising income is more strongly associated with increased tax collections in larger than in smaller states. This is consistent with the less statistically powerful evidence in columns 2-1 and 2-2 that expenditure of larger states exhibits stronger income associations than does expenditure of smaller states. The coefficients imply that increasing the size of an average state by 1 percent of the U.S. population increases the estimated tax revenue change associated with a 1 percent income fluctuation by 22 percent (from 0.667 percent to 0.816 percent). Including federal grants as explanatory variables in the regression reported in column 2-4 has little effect on these estimates, and the coefficients on grants are much smaller in magnitude than are the corresponding coefficients in column 2-2, notably failing to indicate that the spending effects of grants are crowded out through tax reductions.

It is possible to estimate state-specific income sensitivities of government expenditure and tax collections using a modified version of the specification reported in columns 2-2 and 2-4 that substitutes for the terms $\Delta$ income, $\Delta$ income $_{-1}$, population $\times \Delta$ income, and population $\times$ $\Delta$ income $_{-1}$ a complete set of state dummy variables interacted with the sum of the change in log state personal income and its lag. The estimated coefficients on these interactions, plotted against state population in the top panel of figure 2, capture the extent to which the expenditures of different states respond to income changes. California, Massachusetts, Virginia, and Wisconsin exhibit the greatest sensitivity of state government spending to state personal income, and Delaware and Kansas the least. The bottom panel of figure 2 reveals that California, Michigan, Pennsylvania, and Virginia exhibit the greatest sensitivity of tax collections to state personal income, and Delaware and Nebraska are the least sensitive. The figure shows considerable variation across states for both revenue and spending sensitivity but suggests a general positive relationship between both and 
Figure 2. State Size and Income Sensitivity of State Spending and Tax Revenue

Income sensitivity $^{\mathrm{a}}$

\section{Spending}

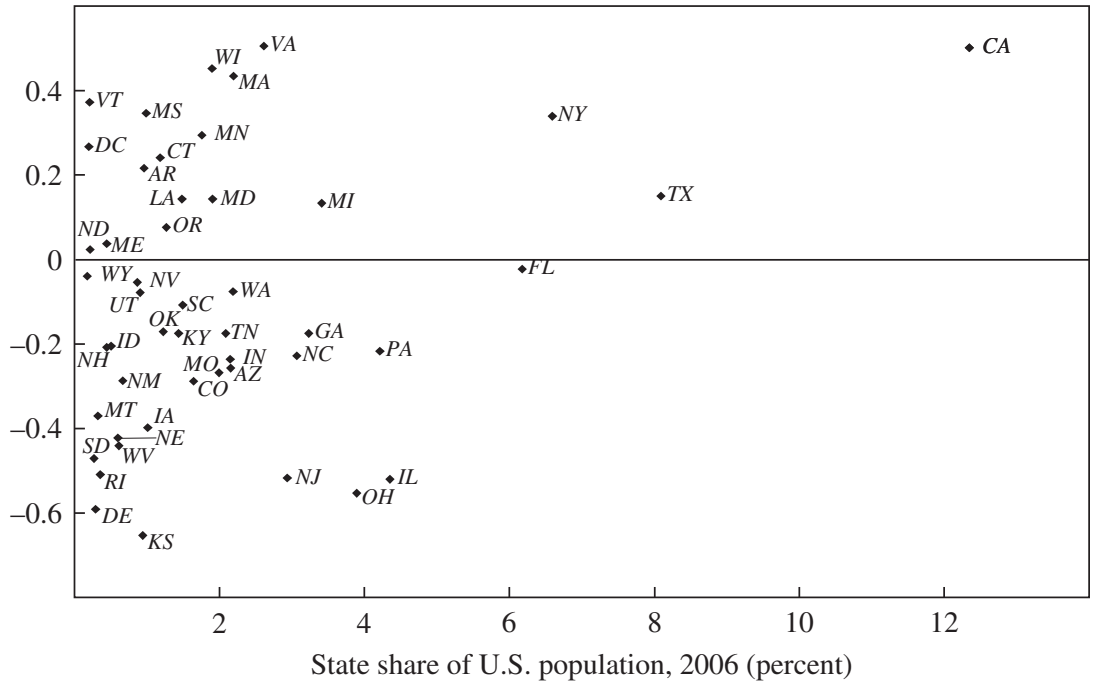

Income sensitivity

\section{Tax revenue}

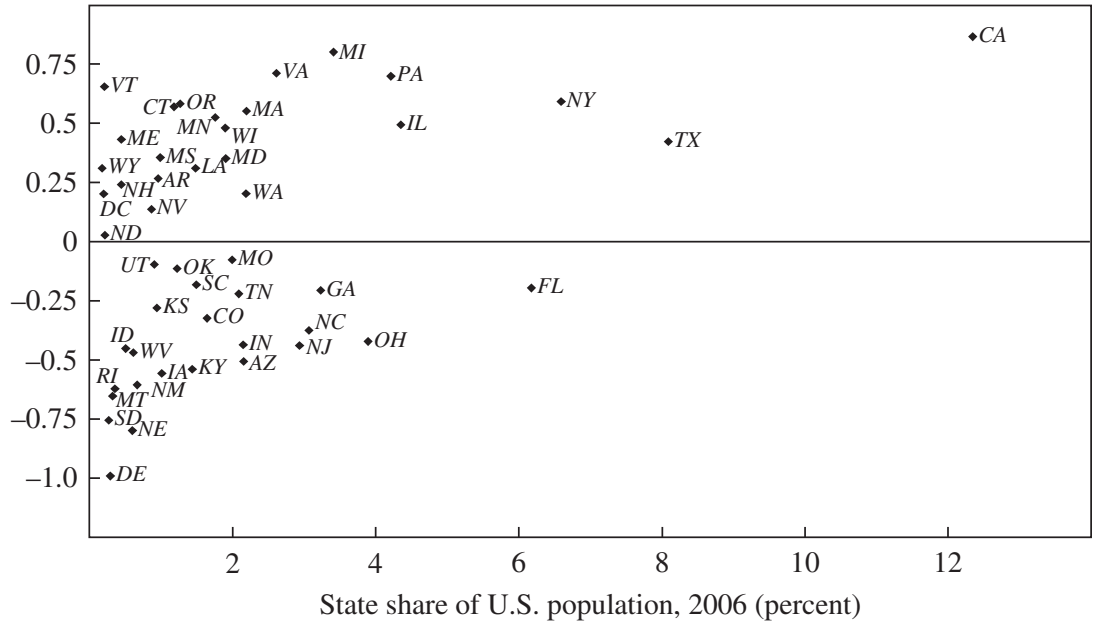

Source: Authors' calculations.

a. State-specific coefficient on the change in real state personal income per capita in a regression in which the dependent variable is the quarterly change in log state expenditure (top panel) or in log state tax revenue (bottom panel). The regression uses the same specification as in column 2-2 of table 2 but substitutes state-specific interactions with the change in income variable for the terms $\Delta$ income, $\Delta$ income $_{-1}$, population $\times \Delta$ income, and population $\times \Delta$ income $_{-1}$. 
state population, with no obvious outliers responsible for the estimation results. As a robustness check, the regressions reported in columns 2-2 and 2-4 were rerun dropping potentially important single states, including California, but the impact on the size and significance of the regression estimates was small.

Further evidence comes from distinguishing state expenditure by function and state tax revenue by source. The first five columns of table 3 report estimated coefficients from regressions in which the dependent variables are log changes in real expenditure per capita on education, health and hospitals, public welfare, highways and roads, and unemployment insurance. These are the five largest state government spending categories; education and public welfare alone accounted for more than half of total state spending in 2006. In these regressions there is a mild association of spending and intergovernmental grants, particularly in the categories of health and hospitals, public welfare, and highways, for which the federal government makes available substantial matching grants. However, the grants variable used in these regressions is total grants received by states; the grants are not distinguished by category, in an effort to avoid the most obvious sources of endogeneity.

The coefficients reported in these first five columns of table 3 imply that interactions of state population shares and income changes have sizable positive effects on the growth rates of education and health and hospital spending, and large but statistically insignificant effects on the growth rate of public welfare spending. In the case of education, the sum of the coefficients on current and lagged income changes interacted with population share is 12.863 (with a standard error of 3.846), which implies that increasing the size of an average state by 1 percent of the U.S. population is associated with roughly one-third greater income sensitivity of education spending. In the case of health and hospitals, the sum of the population and income interaction coefficients is 12.331 (with a standard error of 5.987), which, together with the income coefficients, implies that increasing the size of an average state by 1 percent of the U.S. population is associated with a 26 percent greater income sensitivity of health and hospital expenditure. The sums of the estimated coefficients on the population-income interaction are negative (but insignificant) in the case of highway spending and unemployment insurance, the latter of which expands during economic downturns. In the interpretation that larger states display greater spending responsiveness to transitory income fluctuations, it might be expected that changes in unemployment insurance expenditure, which are negatively associated with income changes, should react with greater magnitude in large states. 


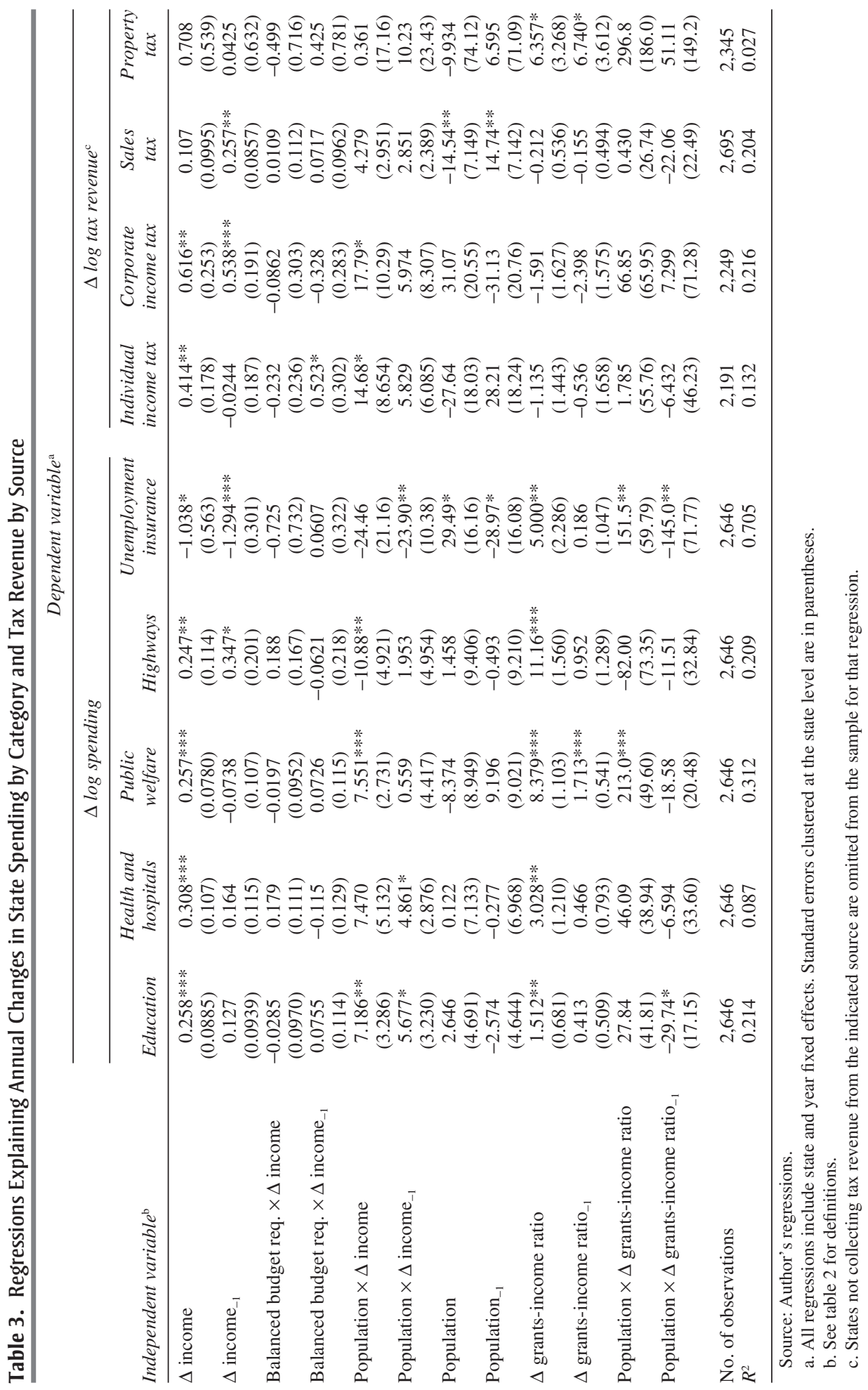


The last four columns of table 3 report coefficients from regressions in which the dependent variables are log changes in real individual income tax collections per capita, corporate tax collections, sales tax collections, and property tax collections. Not all states use all of these taxes-a fact reflected in the varying sample sizes. Among these taxes, corporate and sales tax collections display significant associations with income fluctuations, although the point estimate of income effects on property taxes is large, with a very large standard error. Only in the individual income tax regression is there a significant effect of the interaction between population size and current plus lagged income changes (the sum of current and lagged coefficients is 20.51, with an associated standard error of 8.00); corporate income tax revenue also has a large estimated effect (23.76) but with a large standard error (15.70). As a practical matter, the differing income sensitivities associated with different state taxes make it feasible for state governments to select revenue sources that tailor their revenue streams, within limits, to desired tax collections as incomes fluctuate.

The associations of state size with expenditure and tax responsiveness to changes in state incomes (and changes in federal grant receipts) raise the possibility that other variables correlated with state size may be responsible for this pattern. To the extent that state size matters because larger states have less mobile populations, direct measures of U.S. population mobility might be used in place of state size; and if larger states tend to have more dysfunctional governments, then measures of state government corruption might also be used. D'Vera Cohn and Rich Morin (2008) report the fractions of adult Americans born in each state who continued to live in their state of birth during 2005-07; their figures are reproduced as appendix table 1. (The figures should be interpreted to mean that, for example, 69 percent of current American adults who were born in California continued to live there during 2005-07.) Edward Glaeser and Raven Saks (2006) report average annual convictions of state public officials for federal corruption-related crimes per 100,000 state residents between 1976 and 2002; these data do not include figures for the District of Columbia.

Table 4 presents regressions with the same specifications as those in table 2 but adding as independent variables interactions of measures of population mobility and state corruption with income fluctuations. (Mobility and corruption are time-invariant measures for each state and therefore not included as independent variables.) The results suggest that the results reported above for state size may partially reflect the impact of 
Table 4. Regressions Investigating the Effect of Population Mobility and Corruption on State Spending and Tax Revenue

\begin{tabular}{|c|c|c|c|c|}
\hline \multirow[b]{3}{*}{ Independent variable } & \multicolumn{4}{|c|}{ Dependent variable ${ }^{\mathrm{a}}$} \\
\hline & \multicolumn{2}{|c|}{$\Delta$ log spending } & \multicolumn{2}{|c|}{$\Delta \log$ tax revenue } \\
\hline & $4-1$ & $4-2$ & $4-3$ & $4-4$ \\
\hline$\Delta$ income & $\begin{array}{r}-0.00499 \\
(0.0607)\end{array}$ & $\begin{array}{l}0.145^{* *} \\
(0.0592)\end{array}$ & $\begin{array}{l}0.480 * * * \\
(0.0666)\end{array}$ & $\begin{array}{l}-0.482 * * * \\
(0.0712)\end{array}$ \\
\hline$\Delta$ income $_{-1}$ & $\begin{array}{c}0.165^{*} \\
(0.0843)\end{array}$ & $\begin{array}{r}0.165^{*} \\
(0.0849)\end{array}$ & $\begin{array}{c}0.305 \\
(0.0646)\end{array}$ & $\begin{array}{l}0.306 * * * \\
(0.0690)\end{array}$ \\
\hline $\begin{array}{l}\text { Balanced budget req. } \times \\
\quad \Delta \text { income }\end{array}$ & $\begin{array}{l}-0.0142 \\
(0.0689)\end{array}$ & $\begin{array}{c}-0.0372 \\
(0.0638)\end{array}$ & $\begin{array}{l}-0.133^{*} \\
(0.0761)\end{array}$ & $\begin{array}{l}-0.132 * \\
(0.0764)\end{array}$ \\
\hline $\begin{array}{l}\text { Balanced budget req. } \times \\
\Delta \text { income }\end{array}$ & $\begin{array}{c}-0.0528 \\
(0.0939)\end{array}$ & $\begin{array}{c}-0.0454 \\
(0.0922)\end{array}$ & $\begin{array}{c}0.0619 \\
(0.0735)\end{array}$ & $\begin{array}{c}0.0600 \\
(0.0742)\end{array}$ \\
\hline Population $^{\mathrm{e}} \times \Delta$ income & $\begin{array}{l}-5.297 \\
(3.245)\end{array}$ & $\begin{array}{l}-3.840 \\
(2.932)\end{array}$ & $\begin{array}{c}3.236 \\
(2.350)\end{array}$ & $\begin{array}{l}3.354 \\
(2.420)\end{array}$ \\
\hline Population $\times \Delta$ income $_{-1}$ & $\begin{array}{l}-1.157 \\
(3.134)\end{array}$ & $\begin{array}{c}0.307 \\
(3.145)\end{array}$ & $\begin{array}{l}4.170^{*} \\
(2.368)\end{array}$ & $\begin{array}{c}4.115 \\
(2.490)\end{array}$ \\
\hline Immobility ${ }^{\mathrm{b}} \times \Delta$ income & $\begin{array}{l}1.269 * * \\
(0.520)\end{array}$ & $\begin{array}{l}0.920 * * \\
(0.453)\end{array}$ & $\begin{array}{l}1.983^{* * *} \\
(0.385)\end{array}$ & $\begin{array}{l}2.016 * * * \\
(0.386)\end{array}$ \\
\hline 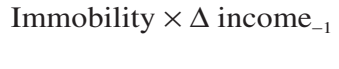 & $\begin{array}{l}1.617 * * * \\
(0.580)\end{array}$ & $\begin{array}{c}0.894 \\
(0.608)\end{array}$ & $\begin{array}{c}0.363 \\
(0.418)\end{array}$ & $\begin{array}{c}0.341 \\
(0.450)\end{array}$ \\
\hline Corruption $^{c} \times \Delta$ income & $\begin{array}{l}0.616 * * \\
(0.245)\end{array}$ & $\begin{array}{l}0.592 * * \\
(0.224)\end{array}$ & $\begin{array}{r}-0.320 \\
(0.284)\end{array}$ & $\begin{array}{c}-0.327 \\
(0.285)\end{array}$ \\
\hline Corruption $\times \Delta$ income $_{-1}$ & $\begin{array}{c}-0.158 \\
(0.334)\end{array}$ & $\begin{array}{c}-0.251 \\
(0.357)\end{array}$ & $\begin{array}{r}-0.0226 \\
(0.281)\end{array}$ & $\begin{array}{r}-0.0159 \\
(0.282)\end{array}$ \\
\hline Population & $\begin{array}{c}-1.956 \\
(4.000)\end{array}$ & $\begin{array}{l}1.478 \\
(3.304)\end{array}$ & $\begin{array}{c}-7.909 * \\
(4.060)\end{array}$ & $\begin{array}{c}-8.298 * \\
(4.205)\end{array}$ \\
\hline Population $_{-1}$ & $\begin{array}{c}2.437 \\
(4.019)\end{array}$ & $\begin{array}{l}-1.068 \\
(3.250)\end{array}$ & $\begin{array}{l}8.147 * * \\
(4.036)\end{array}$ & $\begin{array}{l}8.537 * * \\
(4.188)\end{array}$ \\
\hline$\Delta$ grants-income ratio & & $\begin{array}{l}5.703 * * * \\
(0.572)\end{array}$ & & $\begin{array}{c}0.121 \\
(0.528)\end{array}$ \\
\hline$\Delta$ grants-income ratio ${ }_{-1}$ & & $\begin{array}{l}0.743 * * \\
(0.290)\end{array}$ & & $\begin{array}{r}-0.0774 \\
(0.431)\end{array}$ \\
\hline $\begin{array}{l}\text { Population } \times \Delta \text { grants- } \\
\text { income ratio }\end{array}$ & & $\begin{array}{l}56.63 * * \\
(28.26)\end{array}$ & & $\begin{array}{l}15.45 \\
(22.60)\end{array}$ \\
\hline $\begin{array}{l}\text { Population } \times \Delta \text { grants- } \\
\quad \text { income ratio }-1\end{array}$ & & $\begin{array}{c}-3.067 \\
(10.09)\end{array}$ & & $\begin{array}{c}-17.70 \\
(13.80)\end{array}$ \\
\hline$R^{2}$ & 0.304 & 0.372 & 0.278 & 0.278 \\
\hline
\end{tabular}

Source: Authors' regressions.

a. Dependent variables are annual log changes in real state government spending or tax revenue per capita. All regressions include state and year fixed effects. Sample size is 2,640 in all regressions. Standard errors clustered at the state level are in parentheses. See table 2 for definitions of variables not defined below.

b. Difference between the fraction of adults born in the state who lived there in 2005-07 and the sample mean of 0.5741 .

c. Difference between the average annual number of federal corruption convictions of state government officials per 100,000 state residents during 1976-2002 and the sample mean of 0.2709. 
population mobility; the evidence is weaker in the case of state government performance. In the regression reported in column 4-1, the estimated effect of the interaction of state mobility and income fluctuations is large and statistically significant (the sum of the coefficients is 2.89 , with a standard error of 0.51), indicating that expenditure by states with less mobile populations is more closely associated with income fluctuations than is expenditure by states with more mobile populations. The interaction of corruption and income changes is positive and significant for contemporaneous income changes, but not for the sum of current and lagged changes; the sum of the coefficients on contemporaneous and lagged interactions of population and income changes is also insignificant. Similar results appear with the introduction of the grants variables in the regression reported in column 4-2 and for the tax regressions reported in columns 4-3 and 4-4.

Measured immobility as reported in appendix table 1 has a correlation of 0.53 with state population shares, which in part explains why the population mobility effects in the regressions reported in table 4 look similar to those reported for state size in table 2 . Since population mobility is potentially influenced by state fiscal policies, it may be problematic to treat these variables as strictly exogenous-but the same is true of state population. In both cases there is reason to expect these variables to be related to the underlying mobility of the population, but it is very difficult to distinguish the effect of state size per se from the effects of any other variables that are strongly correlated with state size.

\section{Conclusion}

Tax revenue of state and local governments is more robust in economic downturns than is federal tax revenue, whereas state and local government spending grows at a slower rate in downturns than does federal spending. It is tempting to attribute much of this pattern to choices made long ago about the respective tax bases of federal and subfederal governments. States and localities rely to a much greater extent than does the federal government on property taxes and expenditure-type taxes such as sales and excise taxes, whereas the federal government depends more on income and payroll taxes. State and local revenue might as a result be more stable over the business cycle, and although this does not explain differences in expenditure patterns, it offers a plausible explanation of patterns of tax receipts. One difficulty with this interpretation is that property taxes, which are used almost exclusively by state and local governments, do not appear to be less 
sensitive to income fluctuations than are income taxes; a second is that local, state, and federal governments are entitled to change their funding models at any time if they are dissatisfied with the revenue streams they produce.

It is perhaps surprising that larger states do not have spending and tax policies that more closely resemble those of the federal government, since they are closer in size to the nation as a whole than are smaller states, and their governments may be closer in character to the federal government. Also, as Edward Gramlich (1997) and others note, states-particularly large states - may be able to internalize a large share of the benefits of stimulating their economies when there are underutilized resources. To the extent that larger states have less mobile populations, they are less subject to the point raised by Blanchard and Lawrence Katz (1992) that interstate worker mobility quickly mitigates adverse state economic outcomes (however, see Rowthorn and Glyn 2006 for a contrary interpretation of the evidence). The logic of this argument implies that states with more mobile populations might get smaller returns from trying to increase demand for local factors. Yet the evidence suggests otherwise and therefore may reflect either additional economic considerations or a failure of government optimization.

To the extent that there are national externalities associated with state and local fiscal policies, the federal government has instruments at its disposal that can influence patterns of state and local taxes and spending. The most powerful of these is the provision of grants to state governments. There is ample evidence that state spending is influenced by federal grants, so a carefully tailored countercyclical grant policy has the potential to encourage states, acting on their own behalf, to behave in a manner that effectively incorporates the interests of other states in stimulating the economy when resources are otherwise underutilized.

ACKN OW LED G M ENTS I thank Molly Saunders-Scott and Daniel Schaffa for outstanding research assistance, and Kathryn Dominguez, Bill Gale, Lutz Kilian, Brian Knight, the editors, and participants at the Brookings Panel conference for extremely helpful comments on earlier drafts.

The author reports no relevant potential conflicts of interest. 
APPENDIX

Table A1. Interstate Population Mobility, 2005-07

\begin{tabular}{lclc}
\hline State & $\begin{array}{c}\text { Percent of adults } \\
\text { born in the state } \\
\text { now living there }\end{array}$ & \multicolumn{1}{c}{ State } & $\begin{array}{c}\text { Percent of adults } \\
\text { born in the state } \\
\text { now living there }\end{array}$ \\
\hline Alabama & 63.7 & Montana & 47.1 \\
Alaska & 28.2 & Nebraska & 50.2 \\
Arizona & 61.5 & Nevada & 48.7 \\
Arkansas & 54.5 & New Hampshire & 52.8 \\
California & 69.0 & New Jersey & 55.6 \\
Colorado & 54.7 & New Mexico & 53.5 \\
Connecticut & 57.1 & New York & 55.5 \\
Delaware & 54.0 & North Carolina & 71.4 \\
District of Columbia & 13.0 & North Dakota & 40.4 \\
Florida & 66.0 & Ohio & 65.1 \\
Georgia & 69.6 & Oklahoma & 55.6 \\
Hawaii & 57.3 & Oregon & 59.2 \\
Idaho & 48.6 & Pennsylvania & 63.8 \\
Illinois & 59.0 & Rhode Island & 53.9 \\
Indiana & 62.8 & South Carolina & 66.0 \\
Iowa & 54.0 & South Dakota & 43.4 \\
Kansas & 50.2 & Tennessee & 66.7 \\
Kentucky & 62.6 & Texas & 75.8 \\
Louisiana & 64.4 & Utah & 66.1 \\
Maine & 55.3 & Vermont & 52.5 \\
Maryland & 61.1 & Virginia & 61.9 \\
Massachusetts & 58.7 & Washington & 64.3 \\
Michigan & 67.5 & West Virginia & 48.9 \\
Minnesota & 66.3 & Wisconsin & 68.6 \\
Mississippi & 54.9 & Wyoming & 35.7 \\
Missouri & 61.9 & & \\
Soria Con & & &
\end{tabular}

Source: Cohn and Morin (2008). 


\section{References}

Aizenman, Joshua, and Gurnain Kaur Pasricha. 2010. "On the Ease of Overstating the Fiscal Stimulus in the US, 2008-9.” Working Paper no. 15784. Cambridge, Mass.: National Bureau of Economic Research (February).

Alt, James E., and Robert C. Lowry. 1994. "Divided Government, Fiscal Institutions, and Budget Deficits: Evidence from the States." American Political Science Review 88, no. 4: 811-28.

Auerbach, Alan J., William G. Gale, and Benjamin H. Harris. 2010. "Activist Fiscal Policy." Journal of Economic Perspectives 24, no. 4: 141-64.

Auerbach, Alan J., and Yuriy Gorodnichenko. 2010. "Measuring the Output Responses to Fiscal Policy." Working Paper no. 16311. Cambridge, Mass.: National Bureau of Economic Research (August).

Bahl, Roy. 1984. Financing State and Local Government in the 1980s. Oxford University Press.

Baicker, Katherine. 2005. "Extensive or Intensive Generosity? The Price and Income Effects of Federal Grants." Review of Economics and Statistics 87, no. 2: 371-84.

Barro, Robert J., and Charles J. Redlick. 2009. "Macroeconomic Effects from Government Purchases and Taxes." Working Paper no. 15369. Cambridge, Mass.: National Bureau of Economic Research (September).

Blanchard, Olivier Jean, and Lawrence F. Katz. 1992. "Regional Evolutions." BPEA, no. 1: 1-61.

Blanchard, Olivier, and Roberto Perotti. 2002. "An Empirical Characterization of the Dynamic Effects of Changes in Government Spending and Taxes on Output." Quarterly Journal of Economics 117, no. 4: 1329-68.

Blanchard, Olivier Jean, Florencio Lopez-de-Silanes, and Andrei Shleifer. 1994. "What Do Firms Do with Cash Windfalls?" Journal of Financial Economics 36, no. 3: 337-60.

Bucovetsky, S. 1991. “Asymmetric Tax Competition.” Journal of Urban Economics 30, no. 2: 167-81.

Cogan, John F., Tobias Cwik, John B. Taylor, and Volker Wieland. 2010. "New Keynesian versus Old Keynesian Government Spending Multipliers." Journal of Economic Dynamics and Control 34, no. 3: 281-295.

Cohn, D’Vera, and Rich Morin. 2008. “American Mobility: Who Moves? Who Stays Put? Where's Home?" Social and Demographic Trends Report. Washington: Pew Research Center (December).

Dahlberg, Matz, Eva Mörk, Jørn Rattsø, and Hanna Ågren. 2008. “Using a Discontinuous Grant Rule to Identify the Effect of Grants on Local Taxes and Spending." Journal of Public Economics 92, no. 12: 2320-35.

Feldstein, Martin S., and Gilbert E. Metcalf. 1987. "The Effect of Federal Tax Deductibility on State and Local Taxes and Spending." Journal of Political Economy 95, no. 4: 710-36.

Glaeser, Edward L., and Raven E. Saks. 2006. "Corruption in America.” Journal of Public Economics 90, no. 6-7: 1053-72. 
Gordon, Nora. 2004. "Do Federal Grants Boost School Spending? Evidence from Title I." Journal of Public Economics 88, no. 9-10: 1771-92.

Gramlich, Edward M. 1997. "Subnational Fiscal Policy." In Financing Federal Systems: The Selected Essays of Edward M. Gramlich. Cheltenham, U.K.: Edward Elgar.

Hall, Robert E. 2009. "By How Much Does GDP Rise if the Government Buys More Output?" BPEA, no. 2: 183-231.

Hines, James R., Jr., and Richard H. Thaler. 1995. "The Flypaper Effect." Journal of Economic Perspectives 9, no. 4: 217-26.

Holtz-Eakin, Douglas, Whitney Newey, and Harvey S. Rosen. 1989. "The Revenues-Expenditures Nexus: Evidence from Local Government Data." International Economic Review 30, no. 2: 415-29.

Kanbur, Ravi, and Michael Keen. 1993. "Jeux sans Frontières: Tax Competition and Tax Coordination When Countries Differ in Size." American Economic Review 83, no. 4: 877-92.

Knight, Brian. 2002. "Endogenous Federal Grants and Crowd-Out of State Government Spending: Theory and Evidence from the Federal Highway Aid Program." American Economic Review 92, no. 1: 71-92.

Lutz, Byron. 2010. "Taxation with Representation: Intergovernmental Grants in a Plebiscite." Review of Economics and Statistics 92, no. 2: 316-32.

Poterba, James M. 1994. "State Responses to Fiscal Crises: The Effects of Budgetary Institutions and Politics." Journal of Political Economy 102, no. 4: 799-821.

1997. "Do Budget Rules Work?" In Fiscal Policy: Lessons from Economic Research, edited by Alan J. Auerbach. MIT Press.

Rowthorn, Robert, and Andrew J. Glyn. 2006. "Convergence and Stability in U.S. Employment Rates." Contributions to Macroeconomics 6, no. 1: article 4. www.bepress.com/bejm/contributions/vol6/iss1/art4.

Romer, Christina D., and David H. Romer. 2010. "The Macroeconomic Effects of Tax Changes: Estimates Based on a New Measure of Fiscal Shocks." American Economic Review 100 no. 3: 763-801.

Strumpf, Koleman S. 1998. "A Predictive Index for the Flypaper Effect.” Journal of Public Economics 69, no. 3: 389-412.

Von Hagen, Jürgen. 1991. "A Note on the Empirical Effectiveness of Formal Fiscal Restraints.” Journal of Public Economics 44, no. 2: 199-210.

Wilson, John Douglas, and David E. Wildasin. 2004. "Capital Tax Competition: Bane or Boon?" Journal of Public Economics 88, no. 6: 1065-91.

Woodford, Michael. 2010. "Simple Analytics of the Government Expenditure Multiplier." Working Paper no. 15714. Cambridge, Mass.: National Bureau of Economic Research (January). 


\section{Comments and Discussion}

\section{COMMENT BY}

WILLIAM G. GALE The Great Recession and the associated fiscal policy responses in many countries have renewed research interest in the effects of activist fiscal stabilization and stimulus policies (Auerbach, Gale, and Harris 2010). This paper by James Hines addresses an important but often underanalyzed component of that issue, the role of subnational governments.

In the United States, state and federal governments can have important influences on overall fiscal stimulus for at least three reasons. First, these governments' spending and taxes, which equaled 14 percent and 9 percent of GDP, respectively, in 2009, are sizable relative to those of the federal government. Second, almost all states have balanced budget rules. When revenue falls during a recession, states must either draw down their rainy-day funds, raise taxes, or cut spending; the latter two options are likely to act as procyclical policies that could exacerbate the downturn. James Poterba (1994), for example, finds strong evidence that states contract spending and raise taxes when faced with a negative fiscal shock. He also finds that states with stricter budget rules (for example, those that apply to the enacted budget, rather than just the proposed budget) respond to unexpected deficits by reducing spending much more than other states.

Third, one federal stimulus option-besides raising government purchases, raising transfers to individuals or businesses, or cutting taxesis to provide transfers to the states, which could ease their balanced budget constraints and reduce the need for contractionary state responses. Although the argument that transfers to states are stimulative is 
plausible, there is surprisingly little evidence on their countercyclical effects. ${ }^{1}$

Edward Gramlich (1978, 1979) and Robert Reischauer (1978) evaluate the effects of three federal grant programs undertaken in response to the 1973-75 recession. One program offered countercyclical revenue to the states in the form of block grants, another paid the salaries of state and local government workers, and a third contributed funding for capital improvements. The general finding was that states' short-run response to this federal aid was primarily to bolster their rainy-day funds; increases in outlays and reductions in taxes were modest in the short run. The long-run response-particularly in the form of decreased income tax revenue-was substantial but materialized after the recession had ended. It is unclear how relevant these findings are to the current economic downturn, however, given the dated nature of the evidence, differences between the 1975 economy and today's, and differences between the states' economic situations then and now: in the current downturn, states have been hurt both by the recession and by the housing crisis, which heightened the need for state transfers to local governments due to reduced municipal property tax revenue.

Concerns that state and local government responses to their budget difficulties might undermine federal stimulus efforts are also highlighted by historical considerations. ${ }^{2}$ The classic paper by Cary Brown (1956) shows that states did not conduct countercyclical policy during the Great Depression. Subfederal governments still accounted for the majority of government spending during that era, and in the aggregate they tightened their budgets between 1931 and 1933 and provided no net stimulus between 1933 and 1942.

Likewise, Kenneth Kuttner and Adam Posen (2001) show that during Japan's "lost decade," fiscal efforts at the national level were inconsistent, smaller than commonly thought, and undercut by a variety of factors. Among these was that Japan's announced public spending initiatives turned out to be significantly larger than what ended up being implemented, because many of the announced federal programs required partial local

1. In an analysis of provisions included in the 2009 federal stimulus package, the Congressional Budget Office (2010) estimates output multipliers between 1.0 and 2.5 for transfers to state governments for infrastructure spending, and between 0.7 and 1.8 for transfers for other purposes.

2. The following two paragraphs are based on Auerbach and Gale (2010). 
government funding that did not materialize. Also, coordination issues with local government limited effective planning and implementation.

Hines's paper begins with a demonstration that state activities in the recent downturn through 2009 provided virtually no net stimulus in the aggregate, after accounting for federal grants. Other researchers have reported similar findings for the recent downturn (for example, Aizenman and Pasricha 2010).

With this finding as background, the paper then investigates how state policy has varied over the business cycle in the past, and reaches several major conclusions. First, state-level fiscal policy is less countercyclical than federal policy. This result is as expected, and although the results do not show states running actively procyclical policies as suggested by the simple balanced budget rule analysis above, they still imply that the impact of federal countercyclical policies is smaller than it would be if states acted exactly like the federal government.

Second, large states tend to have more procyclical policies than smaller states. This result may seem backward at first: one might expect larger states to act more like the federal government (which can be thought of as an aggregation of all states) and therefore to behave more countercyclically than small states. However, Hines explains that because smaller states face more elastic populations of taxpayers and businesses, they need to be more responsive to local needs during downturns, and hence need to run more countercyclical policies. In particular, state spending on education and health, and revenue collected through the income tax, are more sensitive to income fluctuations in large states than in small states.

Third, most of the cyclical variation at the state level occurs through changes in revenue rather than in spending. Aggregate state spending is not particularly sensitive to income fluctuations, but taxes are.

The fourth main result is that states have a high propensity to spend federal grants, and this propensity is higher in large states than in small. This is important given the key issue of whether federal grants to states are stimulative. However, the extent to which grant levels are endogenous with respect to state spending levels is difficult to ascertain, which muddies the interpretation.

Policymakers were seeking answers on these issues as they were constructing the American Recovery and Reinvestment Act of 2009, the main federal stimulus package in the recent recession. If and when another stimulus package is debated, whether and in what form to extend aid to the states will continue to be a critical question. At the same time, several other issues would be worth exploring further. The first is the sensitivity of 
Hines's overall results to his use of the whole 1951-2007 time period. The nation experienced only two recessions in the 20 years preceding 2007, and the nature of the aggregate fiscal response to the business cycle changed over that period (Auerbach, Gale, and Harris 2010). It would be interesting to know how robust the results are to a divided sample period.

Second, if the focus is on understanding state responses during economic downturns, it would be interesting to know whether the response to rises versus falls in income is asymmetric because of inertia or political constraints. It is certainly plausible that the response of states to a recession is not the exact opposite of their response to an expansion.

Another issue of interest is how, precisely, states run countercyclical policies, given their balanced budget rules. Do they exploit built-in features of the rules (for example, a requirement that the budget be balanced, but only on an ex ante basis)? Do they exploit the fact that such rules typically apply only to the operating budget, so that debt-financed capital expenditures, one classic type of countercyclical policy, are still possible? Are they running budget surpluses on average, building up reserves, and then draining their rainy-day funds during hard times? Do federal grants in fact enhance their ability to run countercyclical policies? Hines's paper provides a foundation from which future research could explore all of these issues.

\section{REFERENCES FOR THE GALE COMMENT}

Aizenman, Joshua, and Gurnain Kaur Pasricha. 2010. "On the Ease of Overstating the Fiscal Stimulus in the US, 2008-9.” Working Paper no. 15784. Cambridge, Mass.: National Bureau of Economic Research.

Auerbach, Alan J., and William G. Gale. 2009. "Activist Fiscal Policy to Stabilize Economic Activity.” In Financial Stability and Macroeconomic Policy. Federal Reserve Bank of Kansas City.

Auerbach, Alan J., William G. Gale, and Benjamin H. Harris. 2010. "Activist Fiscal Policy." Journal of Economic Perspectives 24, no. 4: 141-64.

Brown, E. Cary. 1956. "Fiscal Policy in the 'Thirties: A Reappraisal." American Economic Review 46, no. 5: 857-79.

Congressional Budget Office. 2010. "Estimated Impact of the American Recovery and Reinvestment Act on Employment and Economic Output from July 2010 through September 2010." Washington (November).

Gramlich, Edward M. 1978. "State and Local Budgets the Day after It Rained: Why Is the Surplus So High?” BPEA, no. 1: 191-216.

- 1979. "Stimulating the Macro Economy through State and Local Governments." American Economic Review 69, no. 2: 180-85.

Kuttner, Kenneth N., and Adam S. Posen. 2001. "The Great Recession: Lessons for Macroeconomic Policy from Japan.” BPEA, no. 2: 93-185. 
Poterba, James M. 1994. "State Responses to Fiscal Crises: The Effects of Budgetary Institutions and Politics." Journal of Political Economy 102, no. 4: 799-821.

Reischauer, Robert D. 1978. "Federal Countercyclical Policy—the State and Local Role." Prepared for the Seventy-first Annual Conference on Taxation of the National Tax Association-Tax Institute of America, Philadelphia, Pa., November 13.

\section{COMMENT BY}

BRIAN KNIGHT In this paper, James Hines investigates differences between state and federal fiscal responses to business cycle fluctuations and delves into cross-state differences in fiscal policy over the business cycle. This is obviously an important topic given both the current economic climate and the fiscal challenges facing both the federal government and state and local governments. Given this importance, I was surprised to learn that Hines's was the first systematic comparison of federal and state-local fiscal policy and thus was delighted to see him tackle this issue. I will first summarize his key findings before turning to some comments on the analysis and a discussion of the results.

The paper's analysis is divided into two parts. The first is a national analysis of quarterly national income and product accounts data covering 1947-2010. Hines finds that federal spending and taxes exhibit the expected countercyclical pattern, with spending rising and taxes falling during recessions identified by the National Bureau of Economic Research (NBER). This result is robust to using the output gap, as defined by the Congressional Budget Office, as an alternative measure of recessions. Hines's corresponding subnational measures of revenue and spending are based on national aggregate data and combine the state and local sectors into one. Using this measure, Hines finds some evidence of a countercyclical pattern in state and local fiscal policy, but one that is smaller in magnitude than the results for the federal government. The state and local results are also less robust than the corresponding federal patterns to measures based on the output gap. Taken together, the key finding from this first analysis is that federal fiscal policy is more countercyclical than state and local fiscal policy.

The second part of the paper is based on annual state-level Census data covering the years 1951-2007. Thus, unlike the aggregate analysis, this analysis excludes data from the most recent recession. Also, this analysis incorporates spending and taxes from state governments alone 
and thus excludes data on fiscal policy at the local level. The key findings here can be summarized as follows. First, fiscal policy does not differ between states with and states without strict balanced budget rules. Second, there is a strong flypaper effect: the marginal propensity of states to spend from federal grants is close to 1 , and about 25 times the marginal propensity to spend from other sources of income. Third, state policy is more countercyclical in states with small populations than in more populous states. Hines interprets this finding as reflecting the fact that large states face less competitive pressure, since voters in these states are less likely to vote with their feet. That is, this pattern of procyclical policy in large states may reflect the suboptimal propensity of politicians to spend, rather than save, budget surpluses during economic booms, and pressures to save any surpluses may be less relevant in large states. As corroborating evidence for this "political failure" interpretation, Hines shows that, conditional on population, fiscal policy is more procyclical in states with less mobile populations, where voting with one's feet is arguably more costly, and in states with high levels of corruption, where these political failures are presumably more salient.

I found the results from the first analysis to be quite convincing in terms of documenting that federal fiscal policy tends to be more countercyclical than fiscal policy at the state and local level. This is certainly consistent with normative principles, as outlined by Wallace Oates (1999), who argues that, in most cases, stabilization policy is best carried out at the central level. This result follows from the fact that state and local governments have open economies and thus neither the means nor the incentives to counteract economic downturns with expansionary fiscal policy. Although this is the conventional wisdom in the federalism literature, Edward Gramlich (1987), as discussed in more detail below, puts forward a case for a more active macroeconomic stabilization policy at the state and local level.

Given Hines's finding of a difference in countercyclicality between the federal government and state and local governments, a natural question is what the root causes of this difference might be. One possible answer is that nearly all states have balanced budget rules, which, by limiting borrowing during recessions, may constrain their ability to conduct countercyclical fiscal policy. One weakness of this interpretation, however, is that it is seemingly inconsistent with another of Hines's findings, cited above, that state fiscal policy is independent of the presence of strict balanced budget rules at the state level. A second possibility derives from the fact that federal taxation is largely based on income, whether individual or corporate, whereas state and local tax bases are more based on sales and property. To the extent 
that income is more volatile than either consumption or land and housing values, then, holding tax rates fixed, federal tax revenue will automatically exhibit more volatility over the business cycle than do state and local tax revenues. Hines provides some evidence in favor of this hypothesis in table 3, but the standard errors in these regressions are quite large, making it difficult to reject the hypothesis that revenues from income, sales, and property tax systems at the state level exhibit similar patterns over the business cycle.

A third possibility, mentioned above, is that because states are less able than the federal government to prevent the benefits of their countercyclical policy from spilling over to other jurisdictions, they have neither the means nor the incentive to counteract a weak economy. But this idea is inconsistent with Hines's finding, also described above, that fiscal policy is more countercyclical in less populous states, which presumably have more open economies and thus less control over economic activity within their borders than do larger states.

A final possibility, not explored in the paper, is that federal tax systems may be more progressive than state tax systems on average, and that this greater progressivity builds greater countercyclicality into federal fiscal policy. All else equal, reductions in individual income under a progressive system tend to move taxpayers into tax brackets with lower tax rates and hence lower tax payments.

As mentioned above, Hines also finds strong evidence of a flypaper effect. In interpreting this result, however, some lessons from the existing literature on the flypaper effect are worth noting. First, many federal grant programs have matching provisions. For example, the federal share of Medicaid spending varies across states from a minimum of 50 percent, consistent with a dollar-for-dollar federal match of state spending, to around 75 percent, consistent with a 3-to-1 federal match. These substantial matching provisions introduce significant substitution effects, and consequently one should not expect the marginal propensity to consume from grants to equal the marginal propensity to consume from income. That is, the standard theoretical prediction of equivalence between grant income and private income is based upon a model with purely lump-sum federal grants. Indeed, Robert Moffitt (1984) investigates this issue in the context of the Aid to Families with Dependent Children program (the predecessor of today's Temporary Assistance for Needy Families) and shows that the flypaper effect can be explained entirely by the program's matching provisions. Second, several recent papers, such as Brian Knight (2002), Nora Gordon (2004), and Byron Lutz (2010), argue that the flypaper effects 
documented in the literature might be explained by endogeneity problems. That is, if federal funds tend to flow to jurisdictions with strong preferences for public spending, then the observed flypaper effects may reflect the presence of this third factor. Moreover, results using exogenous variation in grant receipts tend to exhibit significantly weaker flypaper effects.

I found Hines's results on the differences in fiscal policy between small and large states to be quite interesting, and the idea that political failures of fiscal policy are more salient in large states to be compelling. On the other hand, when one combines this finding with the finding that federal fiscal policy is more countercyclical, one is left with the puzzling result that it is fiscal policy in small states rather than in large states that more closely resembles federal fiscal policy. If differences between small states and large states reflect the differing ability to vote with one's feet, why is the inability to save surpluses during booms not even more of an issue at the federal level, where the population is even less mobile? This issue of differences in fiscal policy between small and large states certainly deserves further exploration.

Regarding this comparison, a potential statistical issue that is not discussed in the paper involves measurement error: any error associated with measuring economic activity may be more pronounced in small states than in large states. This might explain why state taxes and spending more closely track state income in large states than in small states. Although this differential measurement error seems unlikely to entirely explain the differences in fiscal policy that Hines documents, it may lead to their being overstated.

A related fiscal institution not explored in the paper is the rainy-day fund, which, in the context of the author's "political failure" story, can be interpreted as a mechanism through which state governments can commit to saving during economic booms for use during economic contractions. Indeed, many of these funds have provisions designed to address political failure. For example, some states require deposits into the rainy-day fund during favorable economic times, and many allow withdrawals only during downturns. Consistent with the idea that states are unable to commit to saving during booms, Knight and Arik Levinson (1999) document that contributions to these rainy-day funds tend to increase overall state savings on a dollar-for-dollar basis and, moreover, that funds with stricter rules regarding contributions and withdrawals tend to have higher overall savings than funds with more lax rules.

A final issue that this paper raises involves regional business cycles. The first part of the paper is framed around the national business cycle and 
the associated differences in responses to national shocks by the federal government and state and local governments. Yet because some shocks are industry-specific, many recessions have important regional components or might even be limited to one region. Consideration of such spatial variation in business cycles gives rise to a number of interesting issues that are relevant to the paper's results. First, states and localities may be in a better position to respond to local economic shocks than the federal government: state officials may have better information about local economic conditions, or, perhaps for political reasons, the federal government may be unable to respond to highly localized economic shocks. Whatever the reason, the better ability of states and localities to respond to local shocks suggests an important role for state and local governments in macroeconomic stabilization policy (Gramlich 1987).

Second, any federal response to localized economic downturns raises moral hazard considerations. The expectation of increased federal funding for states and localities in fiscal distress may provide incentives for them to run excessive deficits and engage in other risky fiscal practices. To the extent that the federal government cannot commit to not bailing out state and local governments, strict balanced budget rules may be a necessary ingredient of fiscal policy at the state and local level.

Third, federal automatic stabilizers provide a type of insurance against regional contractions: relatively vibrant regions cross-subsidize regions suffering from economic downturns, with the expectation that these roles will be reversed when the economic conditions are reversed. In a careful examination of this issue, Pierfederico Asdrubali, Bent Sørensen, and Oved Yosha (1996) document that about 13 percent of shocks to gross state product are smoothed by federal fiscal policy, with federal taxes, transfers, and grants all providing significant contributions.

In summary, I found this to be a very interesting paper that makes a significant contribution to the literature on stabilization policy and federalism. I hope that this paper will help to stimulate research in this area in the coming years.

\section{REFERENCES FOR THE KNIGHT COMMENT}

Asdrubali, Pierfederico, Bent E. Sørensen, and Oved Yosha. 1996. "Channels of Interstate Risk Sharing: United States 1963-1990." Quarterly Journal of Economics 111, no. 4 (November): 1081-1110.

Gordon, Nora. 2004. "Do Federal Grants Boost School Spending? Evidence from Title I." Journal of Public Economics 88, no. 9-10 (August): 1771-92.

Gramlich, Edward M. 1987. "Subnational Fiscal Policy." Perspectives on Local Public Finance and Public Policy 3: 3-27. 
Knight, Brian. 2002. "Endogenous Federal Grants and Crowd-Out of State Government Spending: Theory and Evidence from the Federal Highway Aid Program." American Economic Review 92, no. 1 (March): 71-92.

Knight, Brian, and Arik Levinson. 1999. "Rainy Day Funds and State Government Savings.” National Tax Journal 52, no 3 (September): 459-72.

Lutz, Byron. 2010. "Taxation with Representation: Intergovernmental Grants in a Plebiscite Democracy." Review of Economics and Statistics 92, no. 2 (May): 316-32.

Moffitt, Robert. 1984. "The Effects of Grants-in-aid on State and Local Expenditures: The Case of AFDC.” Journal of Public Economics 23, no. 3 (April) 279-305.

Oates, Wallace E. 1999. "An Essay on Fiscal Federalism.” Journal of Economic Literature 37, no. 3 (September): 1120-49.

GENERAL DISCUSSION Alan Auerbach noted the lack of a distinction in the paper between automatic and discretionary responses. Presumably some state programs, like some federal programs, are automatically cyclical in their expenditure. It would be interesting to know whether the variation found by Hines relates to differences in these types of programs across states. Are states behaving differently because some but not others are deliberately responding to recessions, or is everything on automatic pilot, and do the differences across states have to do with different compositions of expenditure across these program types? Henry Aaron agreed that the distinction is important, and he suggested that the hypothesis that discretionary tax policy is almost unambiguously procyclical would soon be tested in an effort by the Center on Budget and Policy Priorities to monitor virtually every proposed state tax increase.

Jonathan Parker argued that state income might not be the right dependent variable. A state that cuts back a lot on spending may see a much bigger rebound in income than one that cuts back little or not at all. Also, very high income households account for a large amount of tax revenue in some states. In New York, Wall Street bonuses alone accounted for about $\$ 30$ billion of state income in 2007 , so that when bonuses fell by more than half in 2008, it blew a multibillion-dollar hole in the state budget. This raises the question of whether the recent high cyclicality of high incomes is responsible. Parker noted that that would be the case only for states and localities that rely on the income tax: a state that derives most of its revenue from a progressive income tax is going to have higher revenue cyclicality than one that relies on a flat consumption tax. 
Benjamin Friedman was struck by the differential effect that Hines found between larger and smaller states. Because of spillover effects, one might have thought a priori that countercyclical spending policy, and especially discretionary spending, would be more effective in larger than in smaller states. But then the differential would be in the opposite direction from Hines's finding, leading to the question: is the expected effect offset by other factors?

Steven Davis wanted to see more evidence supporting the theory that smaller states are more efficient in their spending. For example, Hines's argument suggests that smaller states would have more efficient court systems. Is this in fact the case? If the theory is correct, smaller states should perform better on average than larger states on other attributes, too, even the choice of tax base and the quality of public services.

Laurence Ball argued that it might be beneficial to consider a more continuous measure of the business cycle, such as unemployment, rather than a binary indicator like NBER recession dating. He suspected that the results could be quite different. Justin Wolfers added that NBER recessions are defined as times when the economy is getting worse, but active fiscal policy is typically used both in the downswing and on the rebound. Henry Aaron mentioned what he saw as a more fundamental point. At least three of the recessions covered in the paper were caused by cutbacks in defense outlays. This reverses the causation altogether and undermines the relevance of the comparison between state and federal countercyclicality.

Wolfers also noted that when the federal government wants to respond to economic weakness, it can respond forcefully. Much of the time, however, the federal government does not respond at all, perhaps because of politics or gridlock. Aggregating across all states, then, the response of the states may be much more reliable than that of the federal government. Politics has not yet entered into the discussion, but it certainly plays a role.

Robert Hall pointed out that before the early 1960s it was illegal for state and local employees to unionize. Public sector unionization has become important only in recent decades, so that today a governor's job is to figure out how to make up the difference after powerful unions have taken one large share of the revenue needed to balance the budget, and stingy taxpayers have withheld another. In such an environment it is hard to see how a state could possibly act countercyclically. Following up on Parker's comment, Hall noted that another big change is the greater dependence of many states on a progressive income tax, which gathers 
abundant revenue in good times. He also agreed with Ball that focusing on recessions was not the right way of looking at the issue. The need for stimulus is after the end of a recession. A better analysis would be one that compared bad times with good times.

Gary Burtless argued that the discussion of countercyclical stimulus was incomplete without a consideration of the revenue side. As he understood it, the single biggest element of automatic countercyclical stimulus is the loss of income tax revenue from the corporate and personal income tax.

Burtless was also interested in the treatment of unemployment insurance and its allocation between state and federal responsibility. The UI program is essentially mandated by the federal government, but states set the benefit levels and the tax rates on employers to pay for the benefits. An unambiguously discretionary part of policy is the decision whether to provide extensions to UI during downturns. That is entirely a federal initiative, mandated and funded by the federal government, although the state governments write the checks. If such extensions are a large part of what the paper is counting as state stimulus spending, it may not be an accurate characterization.

Refet Gürkaynak was curious whether the difference that Hines observed between small and large states would be found among small and large member states of the European Union. The available history is not as long, but it would be informative to see whether the smaller European states have behaved differently from the larger ones during the last recession and its aftermath.

Donald Kohn noted that the depth of the recent recession and the length and severity of the output gap likely caused many states to run through their rainy-day funds, even if they had built them up as planned. He also wondered whether the dependence of most states on real estate taxes made a difference in this cycle. Because this recession started and was deepest in the real estate sector, the resulting steep loss in property taxes might have cut into state revenue deeper and more quickly than in other recessions. To the extent that states were constrained by a balanced budget, this would have forced them to cut back spending more aggressively than otherwise.

Robert Gordon observed that state and local real spending as a share of potential GDP dropped sharply between 1931 and 1933 and continued to drop throughout the 1930s. Roughly half of the federal stimulus in those years was thus offset by tightening at the state and local level, even before including the tax side. The nation's economic outlook was 
dismal in the second quarter of 1940, but then, in a little over a year, the total government share of spending doubled with the surge in wartime spending. In the recent period, the state and local share of potential GDP has drifted downward steadily since 2003, but the federal government has come nowhere close to offsetting this decline. In fact, it is hard to see any increase in federal government spending on goods and services through the second quarter of 2010. The spending has all been in transfer payments, and most of that in unemployment insurance. 